NOTE

\title{
Specific monoclonal antibodies raised against Taura syndrome virus (TSV) capsid protein VP3 detect TSV in single and dual infections with white spot syndrome virus (WSSV)
}

\author{
Siwaporn Longyant ${ }^{1}$, Piengjan Poyoi ${ }^{1}$, Parin Chaivisuthangkura ${ }^{1}$, \\ Thanawan Tejangkura ${ }^{1}$, Weerawan Sithigorngul ${ }^{1}$, Paisarn Sithigorngul ${ }^{1, *}$, \\ Sombat Rukpratanporn ${ }^{2,3}$
}

\author{
${ }^{1}$ Department of Biology, Faculty of Science, Srinakharinwirot University, Bangkok 10110, Thailand \\ ${ }^{2}$ Center of Excellence for Marine Biotechnology, Chulalongkorn University, Phya Thai Road, Bangkok 10330, Thailand \\ ${ }^{3}$ National Center for Genetic Engineering and Biotechnology (BIOTEC), National Science and Technology Development \\ Agency, Klong 1, Klong Luang Pratum Thani 12120, Thailand
}

\begin{abstract}
The gene sequence encoding VP3 capsid protein of Taura syndrome virus (TSV) was cloned into pGEX-6P-1 expression vector and transformed into Escherichia coli BL21. After induction, recombinant GST-VP3 (rVP3) fusion protein was obtained and further purified by electro-elution before use in immunizing Swiss mice for production of monoclonal antibodies (MAb). One MAb specific to glutathione-S-transferase (GST) and 6 MAb specific to VP3 were selected using dot blotting and Western blotting. MAb specific to VP3 could be used to detect natural TSV infections in farmed whiteleg shrimp Penaeus vannamei by dot blotting and Western blotting, without cross reaction to shrimp tissues or other shrimp viruses, such as white spot syndrome virus (WSSV), yellow head virus (YHV), monodon baculovirus (MBV) and hepatopancreatic parvovirus (HPV). These MAb were also used together with those specific for WSSV to successfully detect TSV and WSSV in dual infections in farmed $P$. vannamei.
\end{abstract}

KEY WORDS: Penaeus vannamei · Monoclonal antibody · MAb · Taura syndrome virus · TSV · VP3 structural protein $\cdot$ White spot syndrome virus $\cdot$ WSSV

\section{INTRODUCTION}

Taura syndrome virus (TSV) is a major viral pathogen first described in cultured whiteleg shrimp Penaeus vannamei (also called Litopenaeus vannamei) in the Western hemisphere (Hasson et al. 1995, 1999, Lightner et al. 1995, Bonami et al. 1997, Lotz 1997, Overstreet et al. 1997). Subsequently, epizootics were reported from Taiwan (Tu et al. 1999) and Thailand (Nielsen et al. 2005), after the introduction of $P$. van- namei from the Americas. Detection of TSV infection is often based on methods for RT-PCR, in situ hybridization (Mari et al. 1998, Nunan et al. 1998) and quantitative real-time RT-PCR (Dhar et al. 2002, Mouillesseaux et al. 2003, Nunan et al. 2004, Tang et al. 2004). Since TSV is widespread, screening large numbers of shrimp is essential to prevent TSV introduction into farming systems at stocking and to monitor for the presence of TSV during cultivation. Since there are no pathognomonic signs for TSV chronic-phase infections, detec- 
tion and identification of TSV by immuno-assay is an alternative low-cost choice for screening large numbers of samples. Chicken and mouse polyclonal antisera and monoclonal antibodies (MAb) against TSV have been produced using purified viral antigens (Poulos et al. 1999). MAb specific to VP1 (designated 1A1) was used to develop Western-blot, dot-blot and immunohistochemical assays for detection of various TSV strains. However, this MAb failed to detect several isolates of TSV from various sources (Erickson et al. 2002, 2005, Robles-Sikisaka et al. 2002). Polyclonal antibodies against recombinant proteins of VP1 and VP3 have also been developed (Chaivisuthangkura et al. 2006). Results similar to MAb $1 \mathrm{~A} 1$ immunoreactivity (Erickson et al. 2005) have been observed in which anti-rVP1 antiserum failed to react in many chronically TSV-infected $P$. vannamei that gave positive results with anti-rVP3 antiserum by immunohistochemistry (P. Chaivisuthangkura unpubl. data). The aim of the present study was to produce MAb specific to VP3 for detection of TSV isolates from different geographical regions. These MAb could also be used for future development of simple and rapid test kits for TSV detection.

\section{MATERIALS AND METHODS}

Viral preparation. Naturally TSV-infected Penaeus vannamei were obtained from farms in Trad and Chantaburi provinces, Thailand. Distal segments of 2 pleopods from each infected shrimp (5 to $10 \mathrm{~g}$ ) were homogenized in $100 \mu$ l of $2 \mathrm{X}$ PBS (0.3 M phosphate buffered saline, $\mathrm{pH} 7.2$ ) then centrifuged at $3000 \times g$ for $30 \mathrm{~min}$. The supernatant solution was dispersed in $0.5 \mathrm{ml}$ aliquots for storage at $-70^{\circ} \mathrm{C}$.

Preparation of recombinant VP3 protein. Escherichia coli BL21 with VP3-pGEX-6P-1 plasmid (Chaivisuthangkura et al. 2006) was cultured in Luria-Bertani (LB) broth to the exponential growth phase and expression of the recombinant protein rVP3 was induced with $1 \mathrm{mM}$ isopropyl- $\beta$-D-thiogalacto-pyranoside (IPTG) for $4 \mathrm{~h}$. After centrifugation at $4000 \times g$ for $20 \mathrm{~min}$, the bacterial pellet was resuspended in $100 \mathrm{mM} \mathrm{NaH} \mathrm{PO}_{4}, 10 \mathrm{mM}$ Tris- $\mathrm{HCl}, 8 \mathrm{M}$ urea $\mathrm{pH}$ 8, containing $1 \mathrm{mM}$ phenylmethylsulfonyl fluoride (PMSF) and sonicated until a clear lysate was obtained. The lysate was resolved using $12 \%$ sodium dodecyl sulphate polyacrylamide gel electrophoresis (SDSPAGE). After staining with Coomassie brilliant blue, the recombinant protein bands were cut, destained and collected in dialysis bags. After elution with a Transblot apparatus (Bio-Rad) at $70 \mathrm{~V}$ for $6 \mathrm{~h}$, the rVP3 was dialyzed and concentrated using a vacuum concentrator (Savant) before determining the protein content by Bradford protein assay (Bradford 1976). The rVP3 solution was divided into $0.5 \mathrm{ml}$ aliquots and stored at $-70^{\circ} \mathrm{C}$.

Immunization. For immunization, the rVP3 protein was mixed with complete Freund's adjuvant at a 1:1 ratio and injected intra-peritoneally into 4 Swiss mice with $0.05 \mathrm{mg}$ protein per mouse. Mice were subsequently injected 3 more times at 2 wk intervals with the recombinant protein mixed with incomplete Freund's adjuvant. One week after the fourth injection, mouse antisera were collected and tested against expressed lysates of Escherichia coli with pGEX-6P-1 and E. coli with VP3-pGEX-6P-1 by Western blotting. The best-performing mouse was boosted $3 \mathrm{~d}$ before harvesting the spleen for hybridoma production.

Production of MAb. A cell-fusion protocol was adapted from the method developed by Köhler \& Milstein (1976) with modifications described by Mosmann et al. (1979). A P3X myeloma cell line was used as the fusion partner. Fusion products from 1 mouse were plated on 30 microculture plates (96 wells plate ${ }^{-1}$ ). After identification of the positive cultures by screening methods, including dot blotting and Western blotting as described below, cells were cloned by the limiting dilution method, expanded and stored in liquid nitrogen.

Specificity testing. Dot blotting: Lysates of Escherichia coli BL21 with pGEX-6P-1, lysates of E. coli with VP3-pGEX-6P-1 or supernatant solution from sample pleopod homogenates $\left(1 \mu \operatorname{spot}^{-1}\right)$ of uninfected shrimp, and TSV-infected shrimp were applied to nitrocellulose membranes. TSV-infection status of the pleopod samples had been confirmed by RT-PCR (Nunan et al. 1998). After being heating in an oven at $60^{\circ} \mathrm{C}$ for $10 \mathrm{~min}$, the membranes were incubated in supernatant medium from full grown hybridoma cell cultures diluted to $1: 20$ dilution in $5 \%$ blotto (5\% nonfat dry milk, $0.1 \%$ Triton X-100 in PBS) for $5 \mathrm{~h}$. After extensive washing in $0.5 \%$ blotto, the membranes were incubated in horseradish peroxidase-labeled goat anti-mouse gamma-immunoglobulin heavy and light-chain-specific antibody (GAM-HRP, Bio-Rad) at 1:1500 dilution for $3 \mathrm{~h}$. The membranes were then washed for $5 \mathrm{~min}$ in blotto and incubated for $5 \mathrm{~min}$ in a substrate mixture containing $0.03 \%$ diaminobenzidine (DAB), $0.006 \%$ hydrogen peroxide, and $0.05 \%$ cobalt chloride in PBS (Sithigorngul et al. 2000).

Western blotting: Lysates of Escherichia coli BL21 with pGEX-6P-1, E. coli with VP3-pGEX-6P-1 and pleopod homogenates (as above) were resolved using $12 \%$ gel SDS-PAGE according to the method described by Laemmli (1970). Samples were electrophoresed for $3 \mathrm{~h}$ at $60 \mathrm{~V}$ and one part of the gel was stained using Coomassie brilliant blue R-250. For Western-blot analysis, the samples resolved by SDS- 
PAGE were electroblotted onto nitrocellulose membranes using a Transblot apparatus (Bio-Rad). The nitrocellulose membranes were incubated in $5 \%$ blotto for $10 \mathrm{~min}$, treated with MAb or mouse anti-recombinant VP3-antiserum (preabsorbed with E. coli lysate containing GST) for $5 \mathrm{~h}$. After extensive washing in $0.5 \%$ blotto, the membranes were incubated with GAM-HRP at 1:1500 dilution for $3 \mathrm{~h}$ before extensive washing, followed by incubation for $5 \mathrm{~min}$ in a substrate mixture containing $0.006 \%$ hydrogen peroxide, $0.03 \% \mathrm{DAB}$, and $0.05 \%$ cobalt chloride in PBS.

Immunohistochemistry: For antibody screening and cross-reactivity testing, archived paraffin blocks of shrimp infected with various shrimp viruses were sectioned (8 $\mu \mathrm{m}$ thickness) and processed for indirect immunoperoxidase staining using primary MAb specific to VP3 or to other viruses; GAM-HRP was used as the secondary antibody. Peroxidase activity was revealed by incubation for 5 min with $0.03 \%$ DAB and $0.006 \%$ hydrogen peroxide in PBS. Preparations were counterstained with haematoxylin and eosin $\mathrm{Y}$ (H\&E), dehydrated in a graded ethanol series, cleared in xylene and mounted in Permount (Sithigorngul et al. 2000). Positive reactions were visualized as brown coloration against pink cytoplasm and purple nuclei.

MAb class and subclass determination. Class and subclass of mouse immunoglobulins produced by the hybridomas were determined by sandwich ELISA using Zymed's Mouse MonoAb ID Kit (HRP).

Cross-reactivity testing. Shrimp samples infected with hepatopancreatic parvovirus (HPV), monodon baculovirus (MBV), white spot syndrome virus (WSSV) and yellow head virus (YHV) were processed for paraffin sectioning and immunohistochemistry using the TSV MAb. The results were compared with those of MAb specific to HPV (HPV6-12B) (Rukpratanporn et al. 2005), WSSV (W29) (Chaivisuthangkura et al. 2004), YHV (Y19) (Sithigorngul et al. 2002) and monodon baculovirus (MBV5-6F) (Boonsanongchokying et al. 2006).

Sensitivity testing. Recombinant VP3 protein was serially diluted with PBS and spotted onto nitrocellulose membranes before processing for dot blotting using various MAb specific to VP3 as described above. The last dilution that gave a clear positive result was determined.

Detection of TSV in naturally infected shrimp. Farmers collected samples of Penaeus vannamei, including 5 shrimp with pinkish coloration ( 5 g) from Trad province, 10 shrimp with smoky coloration or black melanized lesions in the cuticle ( 8 g) from Chantaburi, 20 shrimp with pinkish coloration (20 g) from Panga province, and 10 shrimp with reddish patches at the joints of appendages and 10 with normal coloration from Patoomtani province; the samples were stored at $-20^{\circ} \mathrm{C}$ until used. Distal segments of 2 pleopods were dissected out, homogenized in $50 \mu \mathrm{l}$ PBS, and $1 \mu \mathrm{l}$ of the homogenate was applied to nitrocellulose membranes and processed for dot blotting using MAb specific to VP3 (TSV3-97), WSSV (W29) and YHV (Y19). Pooled supernatant samples from each group of shrimp were checked for the presence or absence of TSV by RT-PCR (Nunan et al. 1998) and for WSSV by 1-step PCR (Chaivisuthangkura et al. 2004). The cephalothorax and uropods from each shrimp were fixed in Davidson's fixative and processed for immunohistochemistry using MAb specific to Vibrio vulnificus (VVB158, authors' unpubl. data) using the methodology described above.

\section{RESULTS AND DISCUSSION}

\section{MAb production}

From one fusion, approximately 800 hybridomacontaining wells were obtained and about 80 wells gave positive binding results with Escherichia coli lysate of GST-VP3 in the first round of screening. The hybridoma clones were further screened by dot blotting against E. coli lysates containing GST or GSTVP3, by Western blotting against pleopod extracts (Fig. 1), and by immunohistochemistry against gill sections from TSV-infected $P$. vannamei. One MAb specific to GST served as a negative control and $6 \mathrm{MAb}$ specific to VP3 were selected and cloned to establish cell lines (Table 1).

\section{Specificity of MAb}

MAb specific to GST bound strongly to Escherichia coli lysates containing GST or GST-VP3, but did not bind to tissues from uninfected and naturally TSVinfected Penaeus vannamei by dot blotting, Western

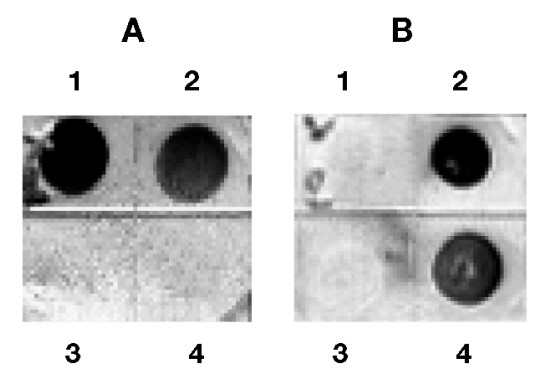

Fig. 1. Dot blot analysis of monoclonal antibodies (MAb). Lysates of (1) Escherichia coli BL21 with pGEX-6P-1 plasmid, (2) E. coli with VP3-pGEX-6P-1 plasmid, (3) pleopod homogenate from uninfected and (4) Taura syndrome virus (TSV)infected Penaeus vannamei were spotted $\left(1 \mu \mathrm{spot}^{-1}\right)$ onto a nitrocellulose membrane and treated with MAb specific to (A) glutathione-S-transferase (GST98) or (B) VP3 (TSV3-97) 
Table 1. Monoclonal antibodies (MAb) obtained from mouse immunized with the GST-VP3 protein. IHC: immunohistochemistry; ND: not determined

\begin{tabular}{|lrrrr|}
\hline $\begin{array}{l}\text { MAb } \\
\text { (Subclass) }\end{array}$ & $\begin{array}{l}\text { Western } \\
\text { blotting }\end{array}$ & $\begin{array}{r}\text { IHC } \\
\text { protein } \text { spot }^{-1} \text { ) }\end{array}$ & \\
\hline GST-98 (IgG1) & + & - & ND & GST \\
TSV3-70, 72,97, & + & + & $400-800$ & VP3 \\
$84,157,169$ (IgG1) & & & \\
\hline
\end{tabular}

blotting or immunohistochemistry. In contrast, none of the MAb specific to VP3 bound to E. coli lysates containing GST or to tissues from uninfected $P$. vannamei. However, all MAb bound to E. coli lysates containing GST-VP3, to pleopod homogenates containing natural VP3 and to tissues from TSV-infected shrimp (Table 1, Figs. 1 \& 2). These results demonstrate specificity of $\mathrm{MAb}$ to recombinant or natural VP3 without cross reaction to E. coli lysates containing GST or to uninfected shrimp tissues.

None of the TSV MAb had cross reactions with tissues from shrimp infected with HPV, MBV, WSSV or YHV (data not shown). In addition, they reacted to only a single band of VP3 protein in pleopod homogenated prepared from TSV-infected shrimp (Fig. 2). In a previous report on MAb specific to purified TSV, cross reactivity was seen with haemolymph from shrimp infected with infectious hypodermal and hematopoietic necrosis virus (IHHNV), YHV and WSSV. In addition, all of the MAb reacted with multiple antigen bands in gels prepared from purified TSV (Poulos et al. 1999). Application of one of the MAb (designated 1A1 and specific to VP1) for immunohistochemical detection of TSV infection in shrimp gave positive results with TSV isolates from Taiwan, USA and Hawaii, but negative results for TSV isolates from Mexico, Nicaragua and Belize (Robles-Sikisaka et al. 2002, Erickson et al. 2005). Phylogenetic analysis of the TSV capsid protein 2 gene (also called CP2 but equivalent to VP1) from various sources revealed 3 distinct geographic groups associated with Belize, the USA and Southeast Asia (Tang \& Lightner 2005). TSV in Thailand is included in the Southeast Asian group (Nielsen et al. 2005, Phalitakul et al. 2006). From amino acid sequence comparisons of structural proteins of TSV and members of the genus Cricket paralysis-like virus, VP1 (CP2) had the least similarity while VP2 (CP1) and VP3 (CP3) had higher similarity (Mari et al. 2002). Therefore, it is likely that MAb specific to VP3 may be useful for detecting a wider variety of TSV isolates. For example, the amino acid sequence of VP3 for Belize isolates is $100 \%$ identical to that of Hawaii isolates (Erickson et al. 2005). However, experimental testing of TSV-infected samples from various geographical regions will be required for confirmation.

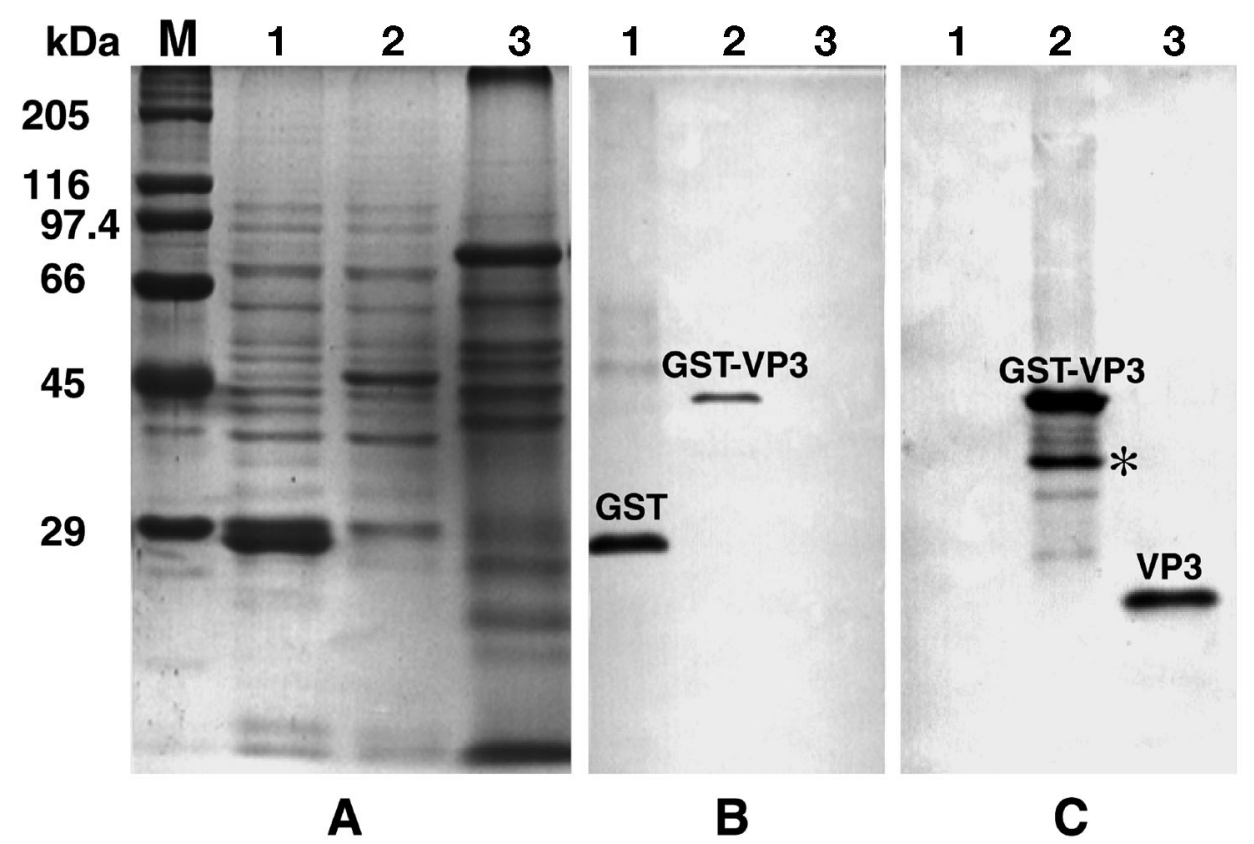

Fig. 2. Western blot analysis of monoclonal antibodies (MAb). Lysates of (Lane 1) Escherichia coli BL21 with pGEX-6P-1 plasmid, (Lane 2) E. coli with VP3-pGEX-6P-1 plasmid and (Lane 3) pleopod homogenate from Taura syndrome virus (TSV)-infected Penaues vannamei were (A) electrophoresed and stained with Coomassie brilliant blue or transferred to a nitrocellulose membrane and treated with monoclonal antibodies specific to (B) glutathione-S-transferase (GST98) or (C) VP3 (TSV3-97). M: standard marker proteins; $*$ : putatively degraded product of GST-VP3 


\section{Sensitivity testing}

MAb specific to TSV detected $\mathrm{rVP} 3$ protein at a level of 400 to $800 \mathrm{pg} \mathrm{ml}^{-1}$ by dot blotting. This is equivalent to about 1 to 2 femtomole of antigen. MAb specific to VP28 of WSSV can detect the protein at $500 \mathrm{pg}$ by indirect immunoperoxidase dot blotting (Anil et al. 2002) and 625 pg by immunocomb detection (Makesh et al. 2006), which is similar to our results. In the case of antigen-capture ELISA, the detection limit for VP28 protein was as low as $20 \mathrm{pg} \mathrm{ml}^{-1}$ (Liu et al. 2002), probably because the sample volume in that method was much larger (50 to $100 \mu \mathrm{l}$ ) than that used for blot or comb methods $(1 \mu \mathrm{l})$.

\section{Detection of TSV infection in naturally infected shrimps}

All 5 shrimp samples with pinkish bodies from Trad gave strong positive results for TSV infection by dot blotting. The pooled RT-PCR test was also positive for TSV (Fig. 3). By contrast, all 10 shrimp samples from Chantaburi gave negative results by dot-blot assay, even though the pooled RT-PCR test for TSV was positive (Fig. 3). Using MAb specific to Vibrio vulnificus, the 10 Chantaburi samples gave strong immunoreactivity in large areas of hepatopancreas. Therefore, the major cause of death on the farm where these samples originated was probably the result of $V$. vulnificus infection rather than TSV.

All 20 pinkish shrimp from Panga province were negative for TSV by dot blotting. In addition, the pooled RT-PCR assay was also negative (Fig. 3). On the other hand, these shrimp were all strongly positive for WSSV by dot blotting and PCR. Since there were no gross signs of white spots in the cuticle of these shrimp, differentiation between disease caused by TSV and WSSV could not be determined based only on observation of gross signs.

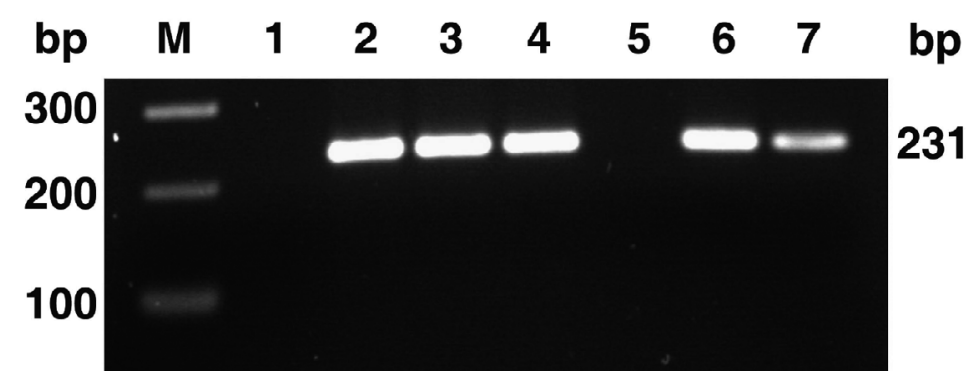

Fig. 3. RT-PCR confirmation of Taura syndrome virus (TSV) infection in pooled samples. M: DNA ladder; Lane 1: negative control; Lane 2: positive control; Lane 3: Penaeus vannamei from Trad; Lane 4: $P$. vannamei from Chantaburi; Lane 5: $P$. vannamei from Panga; Lane 6: $P$. vannamei from Patoomthani with reddish color at the joints of shrimp appendages; or Lane 7 : with normal appearance
Of 10 shrimp samples from Patoomtani province with reddish joints for walking legs and other appendages, 3 gave positive dot-blot test results for TSV (Fig. 4A, Rows 1 and 2). The pooled RT-PCR test was also positive for TSV (Fig. 3). In addition, 8 out of 10 of these shrimp were also positive for WSSV (Fig. 4B, Rows 1 and 2). Surprisingly, another 4 shrimp from Patoomtani with a normal color gave positive results for TSV infection by dot blot (Fig. 4A, Rows 3 and 4). The pooled RTPCR test was also positive (Fig. 3). In addition, 6 out of 10 of these grossly normal shrimp were also positive for WSSV by dot blot (Fig. 4B, Rows 3 and 4) and PCR. Overall, 8 out of the 20 Patoomtani shrimp examined had dual infections of TSV and WSSV.

We have shown that MAb specific to TSV can be used to differentiate TSV infection and WSSV infection by dot blotting (Table 2). Although it is generally recognized to be less sensitive than PCR for pathogen detection (Anil et al. 2002, Liu et al. 2002), immunoassays are easier to perform and cost much less per test. Thus, they are suitable for confirmation of TSV infection, since gross signs of infection, such as reddish color, are unreliable for distinquishing between WSSV and TSV (Flegel 2006) and since histopathological

Table 2. Taura syndrome virus (TSV) infection in farmed Penaeus vannamei. IHC: immunohistochemistry; +: light positive result; ++: intermediate positive result; +++ : strong positive result; - : negative result; no.: number of shrimp

\begin{tabular}{|c|c|c|c|c|}
\hline Source (no.) & Gross signs & $\begin{array}{l}\text { Detection m } \\
\text { Dot blot (no.) }\end{array}$ & $\begin{array}{l}\text { lethod for TSV } \\
\text { Pooled RT-PCR }\end{array}$ & Remarks \\
\hline Trad (5) & Pinkish body & $++(5)$ & +++ & No WSSV detected \\
\hline Chantaburi (10) & $\begin{array}{l}\text { Normal color or smoky color } \\
\text { and/or black lesions in cuticle }\end{array}$ & $-(10)$ & +++ & $\begin{array}{l}\text { Vibrio vunificus infection in hepato- } \\
\text { pancreas by IHC }\end{array}$ \\
\hline Panga (20) & Pinkish body & - & - & WSSV infection by dot blot and PCR (20) \\
\hline Patoomtani (10) & Reddish joint of appendages & $+(3)$ & +++ & WSSV infection by dot blot and PCR (8) \\
\hline Patoomtani (10) & Normal appearance & $+(4)$ & ++ & WSSV infection by dot blot and PCR (6) \\
\hline
\end{tabular}






Fig. 4. Dot-blot detection of Taura syndrome virus (TSV) or white spot syndrome virus (WSSV) in Penaeus vannamei from Patoomthani province. From pleopod extracts of 20 individual shrimp, 10 shrimp showed reddish color at the joints of appendages (Rows 1 and 2) and 10 shrimp had a normal appearance (Rows 3 and 4). Each block in the fifth row was spotted with pleopod extract from uninfected shrimp (N), TSV-infected shrimp (T), yellow head virus (YHV)-infected shrimp (Y), WSSV-infected shrimp (W), and Escherichia coli lysate containing glutathione-S-transferase (E). Nitrocellulose membranes were treated with monoclonal antibodies specific to (A) TSV (TSV3-97) or (B) WSSV (W29). *: Samples that gave positive results for TSV or WSSV by immunohistochemistry

analysis is difficult. It is our intention that the MAb produced in the present study be used to develop simple TSV detection assays such as immunochromatographic strips used for detection of WSSV and YHV (Sithigorngul et al. 2006, 2007).

Acknowledgements. This work was supported by the Thai National Center for Genetic Engineering and Biotechnology (BIOTEC). We thank colleagues at Centex Shrimp, Mahidol University for assistance and Mr. Siriyod Chamchoy, Chareon Phokphan Food Co. at Trad province and shrimp farmers who provided shrimp samples used in this study.

\section{LITERATURE CITED}

Anil TM, Shankar KM, Mohan CV (2002) Monoclonal antibodies developed for sensitive detection and comparison of white spot syndrome virus isolates in India. Dis Aquat Org 51:67-75

Bonami JR, Hasson KW, Mari J, Poulos BT, Lightner DV (1997) Taura syndrome of marine penaeid shrimp: characterization of the viral agent. J Gen Virol 78:313-319

Boonsanongchokying C, Sang-oum W, Sithigorngul P, Sriurairatana S, Flegel TW (2006) Production of monoclonal antibodies to polyhedrin of monodon baculovirus (MBV) from shrimp. ScienceAsia 32:371-376

Bradford MM (1976) A rapid and sensitive method for the quantitation of microgram quantities of protein utilizing the principle of protein-dye binding. Anal Biochem 72: 248-254

Chaivisuthangkura $\mathrm{P}$, Tangkhabuanbutra J, Longyant S, Sithigorngul W, Rukpratanporn S, Menasveta P, Sithigorngul P (2004) Monoclonal antibodies against a truncated viral envelope protein (VP28) can detect white spot syndrome virus (WSSV) infections in shrimp. ScienceAsia 30:359-363

> Chaivisuthangkura $\mathrm{P}$, Tejangkura T, Rukpratanporn S, Longyant S, Sithigorngul W, Sithigorngul P (2006) Polyclonal antibodies specific for VP1 and VP3 capsid proteins of Taura syndrome virus (TSV) produced via gene cloning and expression. Dis Aquat Org 69:249-253

$>$ Dhar AK, Roux MM, Klimpel KR (2002) Quantitative assay for measuring the Taura syndrome virus and yellow head virus load in shrimp by real-time RT-PCR using SYBR Green chemistry. J Virol Methods 104:69-82

Erickson HS, Zarain-Herzberg M, Lightner DV (2002) Detection of Taura syndrome virus (TSV) strain differences using selected diagnostic methods: diagnostic implications in penaeid shrimp. Dis Aquat Org 52:1-10

Erickson HS, Poulos BT, Tang KFJ, Bradley-Dunlop D, Lightner DV (2005) Taura syndrome virus from Belize represents a unique variant. Dis Aquat Org 64:91-98

Flegel TW (2006) Detection of major penaeid shrimp viruses in Asia, a historical perspective with emphasis on Thailand. Aquaculture 258:1-33

Hasson KW, Lightner DV, Poulos BT, Redman RM, White BL, Brock JA, Bonami JR (1995) Taura syndrome in Penaeus vannamei: demonstration of a viral etiology. Dis Aquat Org 23:115-126

Hasson KW, Lightner DV, Mari J, Bonami JR and others (1999) The geographic distribution of Taura syndrome virus (TSV) in the Americas: determination by histopathology and in situ hybridization using TSV-specific cDNA probes. Aquaculture 171:13-26

Köhler G, Milstein C (1976) Derivation of specific antibody producing tissue culture and tumor lines by cell fusion. Eur J Immunol 6:511-519

Laemmli UK (1970) Cleavage of structural proteins during the assembly of the head of bacteriophage T4. Nature 227: 680-685

Lightner DV, Redman RM, Hasson KW, Pantoja CR (1995) Taura syndrome in Penaeus vannamei (Crustacea: Decapoda): gross signs, histopathology and ultrastructure. Dis Aquat Org 21:53-59

Liu W, Wang YT, Tian DS, Yin ZC, Kwang J (2002) Detection of white spot syndrome virus (WSSV) of shrimp by means of monoclonal antibodies (MAbs) specific to an envelope protein (28 kDa). Dis Aquat Org 49:11-18

Lotz JM (1997) Effect of host size on virulence of Taura syndrome virus to the marine shrimp Penaeus vannamei (Crustacea: Penaeidae). Dis Aquat Org 30:45-51

Makesh M, Koteeswaran A, Chandran NDJ, Manohar BM, Ramasamy V (2006) Development of monoclonal antibodies against VP28 of WSSV and its application to detect WSSV using immunocomb. Aquaculture 261:64-71

Mari J, Bonami JR, Lightner DV (1998) Taura syndrome of penaeid shrimp: cloning of viral genome fragments and development of specific gene probes. Dis Aquat Org 33: $11-17$

Mari J, Poulos BT, Lightner DV, Bonami JR (2002) Shrimp Taura syndrome virus: genomic characterization and similarity with members of the genus Cricket paralysis-like viruses. J Gen Virol 83:915-926

Mosmann TR, Baumal R, Williamson AR (1979) Mutations affecting immunoglobulin light chain secretion by myeloma cells I: functional analysis by cell fusion. Eur J Immunol 9:511-516

Mouillesseaux KP, Klimpel KR, Dhar AK (2003) Improvement in the specificity and sensitivity of detection for the Taura syndrome virus and yellow head virus of penaeid shrimp 
by increasing the amplicon size in SYBR Green real-time RT-PCR. J Virol Methods 111:121-127

Nielsen L, Sang-oum W, Cheevadhanarak S, Flegel TW (2005) Taura syndrome virus (TSV) in Thailand and its relationship to TSV in China and the Americas. Dis Aquat Org 63:101-106

Nunan LM, Poulos BT, Lightner DV (1998) Reverse transcription polymerase chain reaction (RT-PCR) used for the detection of Taura syndrome virus (TSV) in experimentally infected shrimp. Dis Aquat Org 34:87-91

> Nunan LM, Tang-Nelson K, Lightner DV (2004) Real-time RTPCR determination of viral copy number in Penaeus vannamei experimentally infected with Taura syndrome virus. Aquaculture 229:1-10

Overstreet RM, Lightner DV, Hasson KW, McIlwain S, Lotz JM (1997) Susceptibility to Taura syndrome virus of some penaeid shrimp species native to the gulf of Mexico and Southeastern United States. J Invertebr Pathol 69:165-176

Phalitakul S, Wongtawatchai J, Sarikaputi M, Viseshakul N (2006) The molecular detection of Taura syndrome virus emerging with white spot syndrome virus in penaeid shrimps of Thailand. Aquaculture 260:77-85

Poulos BT, Kibler R, Bradley-Dunlop D, Mohney LL, Lightner DV (1999) Production and use of antibodies for the detection of Taura syndrome virus in penaeid shrimp. Dis Aquat Org 37:99-106 Robles-Sikisaka R, Hasson KW, Garcia DK, Brovont KE,
Cleveland KD, Klimpel KR, Dhar AK (2002) Genetic variation and immunohistochemical differences among geographic isolates of Taura syndrome virus of penaeid shrimp. J Gen Virol 83:3123-3130

Rukpratanporn S, Sukhumsirichart W, Chaivisuthangkura P,

Editorial responsibility: Timothy Flegel, Bangkok, Thailand
Longyant S, Sithigorngul W, Menasveta P, Sithigorngul P (2005) Generation of monoclonal antibodies specific to hepatopancreatic parvovirus (HPV) from Penaeus monodon. Dis Aquat Org 65:85-89

Sithigorngul P, Chauychuwong P, Sithigorngul W, Longyant S, Chaivisuthangkura P, Menasveta P (2000) Development of a monoclonal antibody specific to yellow head virus (YHV) from Penaeus monodon. Dis Aquat Org 42:27-34

Sithigorngul P, Rukpratanporn S, Longyant S, Chaivisuthangkura P, Sithigorngul W, Menasveta P (2002) Monoclonal antibodies specific to yellow-head virus (YHV) of Penaeus monodon. Dis Aquat Org 49:71-76

Sithigorngul W, Rukpratanporn S, Pecharaburanin N, Longyant S, Chaivisuthangkura P, Sithigorngul P (2006) A simple and rapid immunochromatographic test strip for detection of white spot syndrome virus (WSSV) of shrimp. Dis Aquat Org 72:101-106

Sithigorngul W, Rukpratanporn S, Sittidilokratna N, Pecharaburanin $N$, Longyant $S$, Chaivisuthangkura P, Sithigorngul P (2007) A convenient immunochromatographic test strip for rapid diagnosis of yellow head virus infection in shrimp. J Virol Methods 140:193-199

Tang KFJ, Lightner DV (2005) Phylogenetic analysis of Taura syndrome virus isolates collected between 1993 and 2004 and virulence comparison between two isolates representing different genetic variants. Virus Res 112:69-76

Tang KFJ, Wang J, Lightner DV (2004) Quantitation of Taura syndrome virus by real-time RT-PCR with a Taq Man assay. J Virol Methods 115:109-114

Tu C, Huang HT, Chuang SH, Hsu JP and others (1999) Taura syndrome in Pacific white shrimp Penaeus vannamei cultured in Taiwan. Dis Aquat Org 38:159-161

Submitted: February 15, 2007; Accepted: November 15, 2007 Proofs received from author(s): February 7, 2008 